\title{
Death and Dying as a Literary Device: A Reading of Selected Works by Contemporary Malaysian Writers
}

\author{
Arbaayah Ali Termizi, Nurul Soleha Mohd Noor, and Wan Iman Wan Salim
}

\begin{abstract}
There is no reliable information of death as an experience and it remains until now as an unknown but trustworthy mystery. Hence death has to be encountered in ways known to readers via the help of fiction. In literature death, both physical and physiological exists at many levels. Though the idea of death is infinite, it never fails to provide meaning to the development of a narrative because it contributes to the emotional effects, plots twists, suspense and mysteries. In addition it adds closure to the plot, a closure which is not alien to most detective / crime fiction and horror / ghost stories. Presumably death has to be meaningful in these genres in order to be treated as an important part of human existence and thus elevated its status as a significant literary device. What about other genres? Is it justifiable to use death as the ultimate fear in order to tighten the plot or add weightage to the drama in genres other than the ones mentioned earlier? Thus this paper aims to analyse how death is employed as a literary device by contemporary Malaysian writers and to study whether the fear of death (or the dead) as expounded by Freud is necessary in these works. It shall focus on the ways of dying, the disclosure of death news and other character/s reaction towards the news in selected works in order to answer the research questions. Preliminary findings from this paper are expected to establish the utilization of death as a literary device in works by contemporary Malaysian writers.
\end{abstract}

Index Terms-death, dying, literary device, Freud, contemporary.

\section{INTRODUCTION}

As commonly acknowledged, "the term literary device refers to the typical structures used by writers in their works to convey his or her message(s) in a simple manner to his or her readers. When employed properly, the different literary devices help readers "to appreciate, interpret and analyze a literary work." (“What are Literary Devices?”) [1]. This straightforward definition of literary device highlights its three important functions which are to assist readers to appreciate, interpret and analyse the works. Thus writers do rely heavily on this structure in order to develop the literary elements in their piece. The usage of metaphors, simile, personification among others are means of initiating interest for the readers of a certain literary work and these are popularly used in nearly all genres of literature.

Manuscript received November 20, 2016; revised March 18, 2017. This work was supported by Putra Grant - Inisiatif Putra Siswazah Project Number 9450300.

Arbaayah Ali Termizi and Nurul Soleha Mohd Noor are with the Department of English, Faculty of Modern Languages and Communication, Universiti Putra Malaysia, 43400 UPM Serdang, Malaysia (e-mail: arbaayah@upm.edu.my, soleha.mdnoor@gmail.com).

Wan Iman Wan Salim is with the English Unit, Universiti Kuala Lumpur Malaysia France Institute, 43650 Bangi, Selangor Malaysia (e-mail: waniman74@gmail.com).
A recent reading of an article written by Paul Brandis entitled Death: A Literary Device evokes a different understanding of the usage of literary devices in literature. Though not listed as one of the inherent devices, Brandis does strike a bull's eyes when he claims, "When all else fails, throw in a death scene to create drama." ("Death: A Literary Device") [2] With the current recurring interest in the idea of dying and death, the current authors of this paper can't help but agree with the above statement. Toying with 'death' could be a preliminary indicator to contemporaneous trend in writing and its utilisation as an 'over-emphasized' literary device.

In literature death, both physical and psychological exists at many levels. Though the idea of death is infinite, it never fails to provide meaning to the development of a narrative because it contributes the emotional effects, plots twists, suspense and mysteries. In addition it adds a closure to the plot, a closure which is not alien to most detective/crime fiction, ghost/supernatural stories and mysteries. In short, death has to be meaningful in these genres in order to be treated as an important part of human existence and thus elevated its status as a significant literary device. The question now is what about other genres? Does it justify to use death as the ultimate fear or add weightage to the drama in genres other than detective/crime novels and ghost stories? How does 'death and dying' function in these genres?

\section{THE IDEA BEHIND 'DEATH AND DYING'}

Psychoanalysis fascination with death is not uncommon as well. In Beyond the Pleasure Principle (1940), Sigmund Freud has divided two drives in the humans' psyche. The first one is called the Sexual Drive or Eros and the second one is Death Drive or Thanatos (113) [3]. Death Drive is theorized by Freud as "the task of causing animate organisms to revert to an inanimate state" (113) [3]. This is because "death is a direct consequence of reproduction" (Freud 83) [3]. Freud indicated that death is the purpose of life and sexual drive is only the expression of the will to live (85) [3]. This Death Drive however is repressed within individuals with the replacement of sexual drive which encourages people to seek pleasure in life (87) [3] and they are in perpetual conflict with one another. Freud likened this conflict to the relationship between love and hate that existed in all individuals (87) [3].

As Death Drive may have been repressed by individuals, they are inclined to sublime these desires for death through writing. Hence, literature is a medium used by individuals to broadcast their supposedly repressed longings for death. The fear of death becomes 'fascinating', if we could put in such a way. Death thus becomes significant to every individual and naturally it should be acknowledged as a stage where every 
living organism must face as an ending to one's life story. Writing about death may somehow fulfil a fantasy of an individual going through the stage of death. And it had made them immortal in a way where they do not have to go through 'actual' death. They ponder about death since death is mysterious and none that was dead ever get to tell about the experience to the livings. This mystery is what invokes curiosity among people and hence why death could be a very important element in writing a story. Be it in the form of a ghost, suicide attempt, or homicide, anything that is associated to death intrigues readers. It keeps the readers' interest in a plot. Can death not be used as literary device that stands on its own then? Could its involvement alone in a storyline attract readers?

In brief, this paper aims to read death as an important literary device employs by contemporary Malaysian writers and to study whether the fear of death is necessary in these works. The focus of this paper is to look for the meaning of death through the ways of dying, the disclosure of death news and other character/s reaction towards the news in the selected works. Selected short stories from Tunku Halim's collection entitled Horror Stories and 25 Malaysian Short Stories: Best of Silverfish New Writing 2001-2005 will be used as the basis of comparison in this paper. It is hypothesized that these stories will represent contemporary Malaysian writings trend to discover whether death is still relevant as a device to invoke a reader's interest. Would readers still be 'fascinated' with the works if they can somehow anticipate the death of the characters by the way the death news is disclosed? Are there different or 'unique' ways to prepare the readers for the news? Could the suspense in the story diminish if death is told upfront? Or should death be sudden and less dramatic?

\section{LITERATURE REVIEW}

The idea of death and dying is not new among scholars of psychological school of thought. And it is also not a foreign subject in literary studies by looking at representations of death, the dead or the idea of dying in novels, short stories, poems and other literary mediums. Therefore, death is not a subject unfamiliar by most scholars from different areas and expertise. It is important to look at previous works done by scholars' on death to strengthen the current paper objectives in studying it as a literary device.

Deidre Barrett, a psychologist, conducted studies on death and its meaning in dreams for Behavioral Medicine Program in Harvard Medical School. According to Barrett, death is an archetype that illustrates how human view their mortality and even so, little had been written about it (95) [4]. Her first paper on Dreams of Death (1989) is about determining the frequency of dreams on dying experienced by young adults in a college population and discovering whether the dreams were pleasant or unpleasant tone of experience for them (Barrett 97) [4]. Barrett found that even in healthy young adults who "neither anticipating nor planning their death", dreamt of death but surprisingly, the tone of such dreams is more pleasant in nature (100) [4]. Another paper that Barrett had written on death in dreams is Through a Glass Darkly: Images of the Dead in Dreams (1992) where the issues of death and loss were examined by looking at the frequency of such dreams and the characteristics of the dead in the dreams (Barrett 99) [5] of young adults who had experienced loss of loved ones and are still in the grieving period. There are a few characteristics of the dead in the dreams in which; (a) the dead came back to life, (b) the dead gave advice to the livings, (c) the dead bid goodbye to the livings, and (d) the dead showcased their state of death. Therefore, Barrett found that the dreams in the study "grapple with issues of mortality and loss" (106) [5]. She later indicated that "dreamworld may be an especially important area to attend to in grief counseling, because this is the dominion of the dead in the lives of the living" (107) [5]. Hereby, this statement reveals that death still haunts those who are still alive and that they may come in many forms and will presumably visit the living in dreams due to free-floating unconscious existed in our psyche.

Due to the unconscious repression on the subject of death in our psyche, we tend to be afraid of death. In other words, we experience death anxiety. Two hypotheses had been tested in a paper written by Orehek et al., Interdependent Self-Construals Mitigate the Fear of Death and Augment the Willingness to Become a Matyr (2014), to determine whether; (a) an interdependent self-defined person would be less anxious about death rather than an independent self-defined person is and (b) an interdependent self-defined person would be more willing to self-sacrifice for others compared to an independent self-defined person (Orehek et al. 266) [6]. The study was conducted through five series of experiments and it was found that consistently, the hypotheses are proven correct. However, the study instigated that future research in regards to the influence of culture on death anxiety is necessary to further strengthen the view of the hypotheses due to the differences between eastern and western cultures regarding definition of self in a society (272) [6]. This paper showcases that death is a subject that caused fear among people especially if there is no purpose to it. If death were to occur on people for the sake of the greater good of other people then death would become a meaningful experience even though through self-sacrifice. Nonetheless, not many people supported the view of death being a good thing as stated by Rider in his paper Epicurus on the Fear of Death and the Relative Value of Life (2014) that many people objected to the view since to them, "death is bad for the person who dies ... because it deprives him of goods or good experiences he otherwise would have enjoyed" (2) [7]. However, in support of Epicurean beliefs that "death is not a misfortune for the person who dies" (1) [7] and upon analyzing the beliefs versus the critiques' view on the subject of death, Rider found that by thinking about death, people will value life more (23) [7]. It is the fears of death that "manifest false, unhealthy, and unnatural ways of thinking about what life is about and what makes life good" (23) [7]. Thus, death is not a subject to be avoided. The paper prompts an idea that death is not a 'bad' thing after all and should not be dreaded. Instead, we should accept death since we can't avoid it and focus more on living. After all, death is only "the end of all conscious awareness" (2) [7] and in death, we no longer have to be aware of them.

But what if we are still conscious even in death? In other words, what if we are dead even if we are still alive? In a book chapter, Representations of Death in Don DeLillo's White Noise and Cosmopolis (2016), by Popa, fear of death 
was further investigated in relation to consumerism as experienced by the characters from the two novels by Don DeLillo (261-262) [8]. It was found that in both novels, the characters are afraid of death and try to escape the idea of dying through consumerism whereby in White Noise, the characters turn to TV commercials and drugs to escape the dread of death (Popa 266) [8] and in Cosmopolis, the character chooses death as a solution to being "spiritually vacuous" despite of being "materially wealthy" (Popa 267) [8]. Both novels suggested that though alive, people are dead inside due to their thirst in possessing material well-being and gaining immortality. Despite the fact that Popa stated that "death could be understood formally, as plot-structuring element, reminding one of Greek and Shakespearean tragedy" (262) [8], death is not looked into the chapter as a key element that influence the plot line of the story.

In short, the above reviews uncovered that none of these previous studies had focused on 'death' as a literary device or highlighting the importance of death in a plot structure. Moreover, most of these previous studies are done in a Western concept which could differ to the point of view of death in an Eastern concept like Malaysia as recommended by Orehek et al. in a study of death anxiety that "cross cultural examinations of the fear of death are particularly important in light of the fact that mortality salience effects have been observed in collectivist cultures, including China, Japan, and Iran... Future research is necessary in order to more fully understand the role of culture in death anxiety" (272) [6]. Hence the hypotheses of the current paper will try to prove whether Malaysian contemporary writings are able to stand as interesting readings or will they cease to fascinate readers if there is no 'death' as a literary device in the stories. This is since Malaysian culture itself could differ in its idea of 'death'.

\section{ANALYSES}

Many would avoid discussing death openly fearing many reasons and one of them being, as long as it is not discussed, 'it' could be presumably 'avoided'. Despite its inexplicable nature, death and its ritual could be a problematic theme to be revealed in literary works. Revealing it too soon, the suspense is somewhat 'killed' and waiting too long for death to happen, it becomes an anti-climax for readers. Hence this paper intends to look at literary descriptions of death in these selected works. The description will look at the ways of dying, how the news of death is conveyed and other character/s' reaction towards the news. It will illustrate the elaborate process of anticipating death scene or precisely how the death news is disclosed in the story.

The underlying idea behind this topic is to unveil the many ways the authors reveal 'death scenes' in both anthologies of short stories. The basis of comparison is to show whether death as used by Tunku Halim in his Horror Stories (2014) short stories is similar or different to the selected short in 25 Malaysian Short Stories: Best of Silverfish New Writing 2001-2005 (2006).

Tunku Halim's Horror Stories, published in 2014 features twenty short stories which cover contemporary Malaysia's socio-political issues such as corruption, addiction, adultery among others within paranormal settings. Though many reviewed the collection as 'less horrifying' ("Horror Stories") [9] than Tunku Halim's previous works, it is still in keeping with his 'creepy' takes on what is happening around him. Raihanah further claimed that literature represents a creative illustration of a country's development at a specific time in history and that the 25 Malaysian Short Stories: Best of Silverfish New Writing 2001-2005 gives readers the opportunity to look at Malaysia's social, cultural and political progress at a contemporary level (61) [10]. It was discovered that the collection had utilized two sets of scripts which are the social and personal scripts which portray the concern of the contemporary writings in Malaysia is on the development of a more personal voice rather than a social one. It was also concluded that this contemporary writing signals a move of the country towards "defining a stronger individual voice rather than a purely collective one" (Raihanah 67) [10]. Hence, the collection represents a contemporary multicultural community with current personal and social issues.

TABLE I: HORROR STORIES (TUNKU HALIM)

\begin{tabular}{|c|c|c|c|}
\hline $\begin{array}{l}\text { Title of Short } \\
\text { Story }\end{array}$ & Means of dying & $\begin{array}{l}\text { The death news } \\
\text { disclosure }\end{array}$ & $\begin{array}{l}\text { How other } \\
\text { characters } \\
\text { responded }\end{array}$ \\
\hline $\begin{array}{l}\text { Biggest } \\
\text { Baddest } \\
\text { Bomoh }^{l}\end{array}$ & $\begin{array}{l}\text { Zani, a lady } \\
\text { whom Idris } \\
\text { fancies, dies in a } \\
\text { car accident (23) } \\
{[11]}\end{array}$ & $\begin{array}{l}\text { Cindy Lam, } \\
\text { Idris' officemate, } \\
\text { calls Idris to } \\
\text { inform of Zani's } \\
\text { death } \\
\text { (23) [11] }\end{array}$ & $\begin{array}{l}\text { Idris is initially } \\
\text { in disbelief and } \\
\text { then shocked } \\
\text { because 'Zani' } \\
\text { is in his } \\
\text { apartment } \\
\text { during the call } \\
(23-24)[11]\end{array}$ \\
\hline $\begin{array}{l}\text { Night of the } \\
\text { Pontianak }^{2}\end{array}$ & $\begin{array}{l}\text { Attacked by } \\
\text { pontianak } \\
(28-29)[11] . \\
\text { There are two } \\
\text { deaths in the } \\
\text { story. One is } \\
\text { Fauziah's and } \\
\text { the second one is } \\
\text { Julian's. }\end{array}$ & $\begin{array}{l}\text { Azman, the } \\
\text { protagonist is } \\
\text { informed by the } \\
\text { pontianak herself } \\
(37) \text { [11] and } \\
\text { then, the body of } \\
\text { his friend darted } \\
\text { in front of the car } \\
\text { and Azman faced } \\
\text { a distorted figure } \\
\text { of Julian (42) } \\
\text { [11] }\end{array}$ & $\begin{array}{l}\text { Shocked and } \\
\text { later Azman } \\
\text { himself was } \\
\text { attacked by } \\
\text { Fauziah, the } \\
\text { pontianak (44) } \\
\text { [11] }\end{array}$ \\
\hline $\begin{array}{l}\text { Haunted } \\
\text { Apartment }\end{array}$ & $\begin{array}{l}\text { Previous } \\
\text { apartment } \\
\text { owners } \\
\text { committed } \\
\text { suicide before } \\
\text { Pamela moves in } \\
(53)[11] \\
\end{array}$ & $\begin{array}{l}\text { Informed by a } \\
\text { motherly } \\
\text { neighbour, Mrs. } \\
\text { Razak to the } \\
\text { current owner, } \\
\text { Pamela (53) } \\
{[11]}\end{array}$ & $\begin{array}{l}\text { Pamela feels } \\
\text { shocked and } \\
\text { disbelief } \\
\text { /speechless } \\
\text { (53) [11] }\end{array}$ \\
\hline $\begin{array}{l}\text { A Labor Day } \\
\text { Weekend }\end{array}$ & $\begin{array}{l}\text { Belinda is } \\
\text { attacked/shocked } \\
\text { by an evil being } \\
\text { from a jar that } \\
\text { her husband, } \\
\text { Hong brings } \\
\text { home from his } \\
\text { unplanned trip } \\
\text { with his best } \\
\text { friend, Arul } \\
(79-81) \text { [11] }\end{array}$ & $\begin{array}{l}\text { Hong witnesses } \\
\text { the death of his } \\
\text { own wife in their } \\
\text { house (80) [11] }\end{array}$ & $\begin{array}{l}\text { In denial, Hong } \\
\text { keeps asking } \\
\text { what happen if } \\
\text { he does not } \\
\text { bring the bottle } \\
\text { back (81-82) } \\
\text { [11] and partly } \\
\text { blames his best } \\
\text { friend, Arul for } \\
\text { asking him to } \\
\text { go for the trip. }\end{array}$ \\
\hline $\begin{array}{l}\text { The Rape of } \\
\text { Martha Teoh }\end{array}$ & $\begin{array}{l}\text { Martha's } \\
\text { husband, Heng } \\
\text { Wan dies of } \\
\text { cancer (85) [11] }\end{array}$ & $\begin{array}{l}\text { Illness } \\
\text { discovered one } \\
\text { day about } 10 \\
\text { years ago }(85) \\
\quad[11]\end{array}$ & $\begin{array}{l}\text { Martha is in } \\
\text { denial and } \\
\text { keeps insisting } \\
\text { that the } \\
\text { husband is still }\end{array}$ \\
\hline
\end{tabular}

${ }^{1}$ Bomoh is a Malay term for shaman or traditional medicine man

${ }^{2}$ Pontianak is a Malay term for banshee 


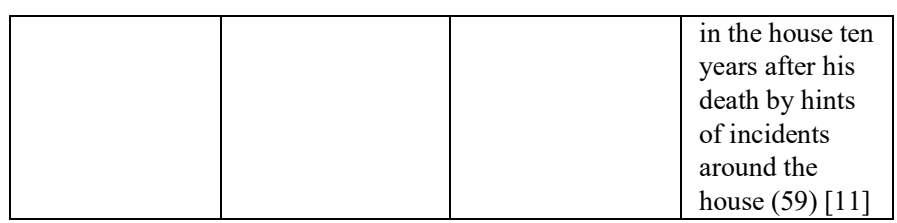

The analysis will be illustrated by the two tables below:

From the above Table I, the five characters who are affected by the death news show initial reaction of shock and disbelief while acknowledging the fact that 'death' is already repressed within their psyches due to the manifestation of their death drives. Idris who fancies Zani and seeks the help of a bomoh (shaman) to woo her in Biggest Baddest Bomoh is shocked to learn of her death while 'she' is 'physically' in the same room with him. The same reaction is also shown by Azman in Night of the Pontianak when he was attacked by the same pontianak/friend, Fauziah who invited him to join their spontaneous banshee hunting endeavour. In the Haunted Apartment and The Rape of Martha Teoh, both protagonists thought that they could find solace in their homes but later discovered that 'death' has no intention to leave them alone and safe. Alas the character, Hong in $A$ Labor Day Weekend who always wishes he has more control in his house is in denial when his wish is finally granted via the 'supernatural encounter'.

Contrary to Tunku Halim's collection, most of the characters in Table II above did not experience shock and disbelief as a reaction to the news of the death. Their acknowledgement of the death turns out to be different kinds of reaction in effect to their lives. There are two types of reaction formed by these characters in dealing with death which include; (a) inspiration and (b) sadness. In three of the selected short stories, the characters are inspired because of the death and plan to change their way of life afterward. Shane in Chewing Gum Boy is inspired to change the fate of other kids through writing, the relatives in $A$ Wedding and $A$ Funeral are inspired to understand the challenge of marriage and communal life because of a letter written by the dead, and the nameless protagonist in Pieces is inspired to change his perception about the world and people in general in effect of the death. Meanwhile, in two other short stories, the characters are emotionally affected of the death. Jane in Death Watch feels sad and helpless for her husband's death while Jeanie and her friend in The Tamarind Tree feel sad for the separation caused by the death of Jeanie's father.

\section{CONCLUSION}

In short, there are two kinds of effects present from the two collections in relation to 'death' which are; (a) the latency of death drives presence in the psyche of the characters before death which materialized into a supernatural form in Horror Stories by Tunku Halim, and (b) the latency of death drives in the psyche of the characters after death which internalized as a metaphysical form in 25 Malaysian Short Stories: Best of Silverfish New Writing 2001-2005. These two effects instigate the crucial existence of 'death' in stories. 'Death' can be seen as a literary device where it sparks or in other words, it fascinates the readers to read the stories and to understand the plot of the stories. Without 'death' in the stories, the effects of materialization and internalization of repressed death drives in sublimed way would not have been substantial. 'Death' should then be considered as a literary device because of the importance of its effects on readers as a representation of humanity's repressed desires for death.

TABLE II: 25 MALAYSIAN SHORT STORIES: BeSt OF SiLVERFISH NEW WRITING 2001-2005

\begin{tabular}{|c|c|c|c|}
\hline $\begin{array}{l}\text { Title of short } \\
\text { story }\end{array}$ & Means of dying & $\begin{array}{l}\text { The death news } \\
\text { disclosure }\end{array}$ & $\begin{array}{l}\text { How other } \\
\text { characters } \\
\text { responded }\end{array}$ \\
\hline Death Watch & $\begin{array}{l}\text { Harry chokes } \\
\text { to death from } \\
\text { eating chicken } \\
\text { that he bought } \\
\text { for his wife in } \\
\text { hope that his } \\
\text { wife will get } \\
\text { fatter and die } \\
\text { more quickly } \\
\text { (99) [12] }\end{array}$ & $\begin{array}{l}\text { Harry's wife, } \\
\text { Jane sees her } \\
\text { husband dies in } \\
\text { front of her } \\
\text { (99) [12] }\end{array}$ & $\begin{array}{l}\text { Jane feels sad } \\
\text { and helpless over } \\
\text { her husband's } \\
\text { death as she is fat } \\
\text { and cannot get } \\
\text { up to help her } \\
\text { husband (100) } \\
\text { [12] }\end{array}$ \\
\hline $\begin{array}{l}\text { Chewing Gum } \\
\text { Boy }\end{array}$ & $\begin{array}{l}\text { Tai, a homeless } \\
\text { kid that Shane } \\
\text { had grown fond } \\
\text { of, is killed by } \\
\text { some bad } \\
\text { people (148) } \\
\text { [12] }\end{array}$ & $\begin{array}{l}\text { Shane finds } \\
\text { Tai's naked } \\
\text { dead blue body } \\
\text { in his } \\
\text { refrigerator } \\
\text { (148) [12] }\end{array}$ & $\begin{array}{l}\text { Shane feels } \\
\text { guilty and deeply } \\
\text { affected by the } \\
\text { death and thinks } \\
\text { of all the } \\
\text { possibility to } \\
\text { change the past. } \\
\text { He leaves the } \\
\text { country behind } \\
\text { and plans to do } \\
\text { something in } \\
\text { hope to change } \\
\text { the future instead } \\
\text { (148) [12] }\end{array}$ \\
\hline $\begin{array}{l}\text { A Wedding and } \\
\text { a Funeral }\end{array}$ & $\begin{array}{l}\text { Joseph } \\
\text { Achayan dies } \\
\text { because of an } \\
\text { illness (158) } \\
{[12]}\end{array}$ & $\begin{array}{l}\text { His wife, } \\
\text { Kochama, tells } \\
\text { the relatives } \\
\text { about the death } \\
\text { (158) [12] }\end{array}$ & $\begin{array}{l}\text { They are sad but } \\
\text { even in death, } \\
\text { Joseph Achayan } \\
\text { a.k.a Joe Annoni } \\
\text { still has his } \\
\text { effects on other } \\
\text { people through } \\
\text { the writings of } \\
\text { his anonymous } \\
\text { letter (163) [12] }\end{array}$ \\
\hline $\begin{array}{l}\text { The Tamarind } \\
\text { Tree }\end{array}$ & $\begin{array}{l}\text { Uncle Das } \\
\text { commits } \\
\text { suicide by } \\
\text { burning } \\
\text { himself under a } \\
\text { tamarind tree } \\
\text { (194) [12] }\end{array}$ & $\begin{array}{l}\text { A little girl } \\
\text { who is the } \\
\text { friend of Uncle } \\
\text { Das' daughter, } \\
\text { sees the deed } \\
\text { happened right } \\
\text { in front of her. } \\
\text { The suicide } \\
\text { becomes the } \\
\text { gossip among } \\
\text { neighbours } \\
\text { (194) [12] }\end{array}$ & $\begin{array}{l}\text { The family and } \\
\text { neighbours } \\
\text { couldn't accept } \\
\text { the news. The } \\
\text { death leads some } \\
\text { people to feel sad } \\
\text { while others turn } \\
\text { it a topic of } \\
\text { gossip and it also } \\
\text { leads to } \\
\text { separation } \\
\text { between two } \\
\text { little girls (Uncle } \\
\text { Das' daughter, } \\
\text { Jeanie and her } \\
\text { friend) } \\
\text { (196-197) [12] }\end{array}$ \\
\hline Pieces & $\begin{array}{l}\text { A nameless } \\
\text { colleague of a } \\
\text { nameless } \\
\text { protagonist } \\
\text { commits } \\
\text { suicide by } \\
\text { jumping off } \\
\text { from the office } \\
\text { building's top } \\
\text { floor (237-238) } \\
\text { [12] }\end{array}$ & $\begin{array}{l}\text { The } \\
\text { protagonist } \\
\text { sees the deed } \\
\text { and also hears } \\
\text { rumours from } \\
\text { others } \\
\text { regarding the } \\
\text { death } \\
(237-238)[12]\end{array}$ & $\begin{array}{l}\text { The protagonist } \\
\text { comes to a } \\
\text { realization that } \\
\text { he himself is } \\
\text { insignificant and } \\
\text { just a small piece } \\
\text { of the big world. } \\
\text { It leads him to a } \\
\text { self-actualization } \\
\text { (239) [12] }\end{array}$ \\
\hline
\end{tabular}

\section{REFERENCES}

[1] What are Literary Devices? Literary Devices. [Online]. Available: $\mathrm{http}: / /$ literarydevices.net/literary-devices 
[2] P. Brandis. Death: A Literary Device. Authorsden. [Online]. Available: http://www.authorsden.com/visit/viewArticle.asp?id=969

[3] F. Sigmund, Beyond the Pleasure Principle and Other Writings, 4th ed., J. Reddick, Trans., A. Phillips, Ed. Penguin Books, 2003.

[4] B. Deirdre, "Dreams of death," OMEGA: Journal of Death and Dying, vol. 19 , no. 2, pp. 95-101, 1989.

[5] D. Barret, "Through a glass darkly: Images of the dead in dreams," OMEGA: Journal of Death and Dying, vol. 24, no. 2, pp. 97-108, 1992.

[6] E. Orehek, J. A. Sasota, A. W. Kruglanski, and M. Dechesne, "Interdependent self-construals mitigate the fear of death and augment the willingness to become a martyr," Journal of Personality and Social Psychology, vol. 107, no. 2, pp. 265-275, 2014.

[7] B. A. Rider, "Epicurus on the fear of death and the relative value of life." Journal for Ancient Philosophy and Science, vol. 47, no. 4, pp. 1-24, 2014.

[8] N.-A. Popa, "Representations of death in Don DeLillo's white noise and cosmopolis," in Expressions of Fear from Antiquity to the Contemporary World, M.-L. D. Oancea, A.-C. Halichias, and N.-A. Popa, Eds. 2016, pp. 261-269.

[9] Horror Stories by Tunku Halim. Goodrreads. [Online]. Available: http://www.goodreads.com/book/show/20617999-horror-stories

[10] M. M. Raihanah, (2011). "New Writings in Malaysia: Issues and Concerns," in Gender, Multiculturalism, and Re-visioning: Creating and Fostering Literary Communities, M. M. Raihanah et al., Eds. Selangor: University Putra Malaysia Press, pp. 59-69.

[11] T. Halim, Horror Stories, Fixi Publication, 2014.

[12] S. Nesa, 25 Malaysian Short Stories: Best of Silverfish New Writing $2001-2005$, Silverfishbooks, 2006.

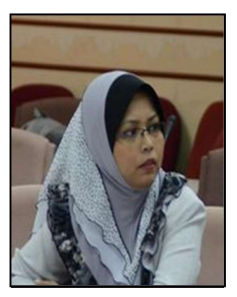

Arbaayah Ali Termizi is an associate professor in the Department of English, Faculty of Modern Languages and Communication, Universiti Putra Malaysia. Her prominent research focus is in the Shakespearean playtexts. She is also interested in interdisciplinary studies of contemporary issues in the world of English Literature.

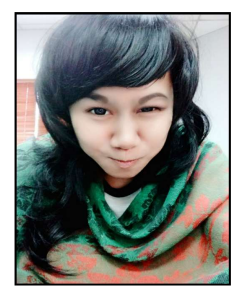

Nurul Soleha Mohd Noor is a master degree student by research of a local university in the field of English Literature. Her research interests would be on gender studies and psychoanalysis specifically in the exploration of the cultural construction on gender, psychodynamic theory, sexual trauma, and death instinct.

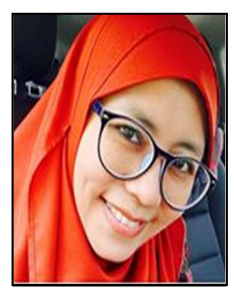

Wan Iman Wan Salim is currently pursuing for a $\mathrm{PhD}$ in applied comparative linguistics from Universiti Putra Malaysia (UPM). She was born in September 1974 in Cairo, Egypt, the author received early primary and secondary education in Malaysia and Scotland in 1980-1991. The author obtained B.HSc. in English Language and Literature from International Islamic University Malaysia (IIUM) in 1996/97 before pursuing for M.HSc. in Literary Studies from the same institution (1998/2000). To kick start her career in 1999, Ms. Iman served as a tutor with Universiti Putra Malaysia until 2003. Since 2006, she has been teaching English at University Kuala Lumpur Malaysia France Institute (UniKL MFI). She is also a member of Asia TEFL and is passionate about education psychology, language learning strategies and motivation in language learning. 